\title{
Is Sexual Assault a Problem in Greek Prisons? Initial Evidence from a Greek Male Prison
}

\author{
Maria Papadakaki ${ }^{1} *$ D, Angelos Tsalkanis ${ }^{2}$, Dimitra Prokopiadou ${ }^{3}$, Martha Goutsou ${ }^{1}$ and \\ Joannes Chliaoutakis ${ }^{1}$ \\ 1 Department of Social Work, Hellenic Mediterranean University, 71004 Heraklion, Greece; \\ martgou@yahoo.gr (M.G.); jchlia@staff.teicrete.gr (J.C.) \\ 2 Department of Social Work, University of West Attica, 12241 Athens, Greece; tsalkanis@gmail.com \\ 3 Health Care Centre of Arkalochori, 70300 Heraklion Crete, Greece; dprokopiadou@gmail.com \\ * Correspondence: mpapadakaki@yahoo.gr; Tel.: +30-2810-379-518
}

Received: 13 September 2019; Accepted: 25 November 2019; Published: 28 November 2019

\begin{abstract}
This study aimed to explore the problem of inmate sexual victimization in a Greek male prison. A total of 400 individuals were approached in the largest Greek male prison and 50 individuals participated. The questionnaire examined sociodemographic, offence-related information, sexual victimization during incarceration, experiences of witnessing the sexual coercion of other inmates, and history of sexual victimization. Thirteen (26.0\%) participants reported sexual victimization by an inmate, including either "only non-penetrative" or "only penetrative ones" or "both penetrative and non-penetrative" ones. The victimized participants also performed worse in child sexual victimization and self-esteem scores as compared with the non-victimized ones. Vulnerable groups identified in the current study could receive further attention in future studies and policy initiatives. Large-scale surveys could be designed to extend our knowledge on this neglected area of research.
\end{abstract}

Keywords: sexual assault; coercion; inmates; prison; offence; self-esteem

\section{Introduction}

It is common for some inmates to trade goods for drugs or even to use sex in order to arrange their debts with other inmates when they lack resources. However, sexual intercourse in prison is not always consensual and for many years sexual assault remains a main problem for prisoners with certain consequences for institutional life. Inmate-on-inmate rape is a serious human rights abuse and a major public health problem. A Human Rights Watch Report [1] identified the huge traumatic effect of male rape on victims' psychology with an emphasis placed on the feelings of shame. A high potential of suicide has also been evident among sexually victimized inmates as a result of desperateness and helplessness. It is also common for inmates to take precautions against sexual assault that render their environment more dangerous, such as launching pre-emptive strikes or joining gangs for protection; some even get injured while defending themselves [2]. Most importantly, there is a public health concern due to the extent that sexual assault contributes to the transmission of HIV among the population of inmates because of unprotected sexual activity [3-5].

\subsection{Theoretical Explanations and Prevalence Estimates of Sexual Misconduct in Correctional Settings}

Predators in prison ordinarily are primarily heterosexual, but they have been said to sexually assault other male prisoners in an attempt to gain control over those who are weak [6]. On the basis of the conceptual framework of hegemonic masculinity, some argue that male rape reflects society's expectations for men to be forceful and pervasive, with male rape being the worst manifestation of power against the weak through gaining control over their body [7-9]. 
The importation and the deprivation model have been widely employed as explanatory frameworks of prison violence [10]. On the one hand, the importation model holds an individual inmate's proneness to violence responsible for violence, and underlines the fact that predators have a personal history that explains their inclination to violence. On the other hand, the deprivation model holds environmental factors responsible for violence and suggests that prison life together with forced isolation, traumatize individuals and generate an oppositional prison subculture, promoting violence for self-preservation. In addition, the transactional model introduces another explanation of prison violence, focusing on the dynamic interaction of prisoners' individual characteristics and the prison environment [11].

Sexual assault seems to be very prevalent in prison settings. Most studies typically report a high incidence of sexual aggression ( $11 \%$ to $40 \%$ ), and a lower incidence of rape (1\% to $3 \%$ ) [12]. However, estimations seem to vary across geographical settings, and this is partly attributed to the variety of methodologies employed in international research. In Australia, 26\% of male inmates aged 18 to 25 years reported experiences of sexual assault, and $8 \%$ were assaulted weekly or daily [13]. In U.S. state prisons, one in every five male inmates reported experiences of sexual misconduct with $7 \%$ being raped [14]. A Bureau of Justice Statistics (BJS) survey identified that $4.5 \%$ of federal prisoners were sexually victimized over a period of one year [15]. In 2011, the U.S. National Prison Rape Statistics Program (NIS 3) identified a total of $4.0 \%$ of prison inmates and $3.2 \%$ of jail inmates that revealed experiences of sexual victimization [16]. A total of $9.6 \%$ of former U.S. state prisoners reported sexual victimization during their latest period of incarceration [17]. Apart from Australia and USA, research from other parts of the world on risk factors of victimization is scarce, especially regarding demographic, behavioral health, and criminal parameters [18]. In fact, the first population-based study on male sexual misconduct in Australia was only published in 2016 [19] while data from Europe are scarce and very local. However, due to the institutional, cultural, and historical differences, USA and Australian findings may not be generalizable to other contexts [19]. A lot of challenges also exist with understanding and recording sexual coercion among juvenile prisoners, and system shortcomings have been recently noticed [20].

\subsection{Sexual Misconduct and Human Rights' Protection in the Greek Correctional Settings}

Rape and sexual misconduct in prison constitute violations of human rights and they are considered to be acts of torture [21]. At the international level, there are conventions and treaties prohibiting torture (e.g., the Convention against Torture and Other Cruel, Inhuman or Degrading Treatment or Punishment [21] and the International Covenant on Civil and Political Rights [22]), explicitly stating that prisoners, like all citizens, have civil and political rights and should not be subjected to degrading treatment. In 2002, a new system (Convention against Torture, CAT) was introduced for the prevention of torture and ill-treatment in correctional facilities, which involved regular visits by international bodies, for the oversight of prison conditions, as well as the detection of degrading treatment.

Although Greece ratified CAT in 1988 and OPCAT (Optional protocol to the Convention against Torture and Other Cruel, Inhuman or degrading Treatment or punishment) in 2014, the subject of inmates' sexual victimization has not been explored efficiently due to its sensitive nature and, so far, there is no known published data estimating the extent of the problem and its correlates in Greek prisons. There are a few studies on various behaviors of incarcerated sexual offenders [23,24] but none of them have been designed to assess the problem in the general population of Greek inmates. Moreover, there is no database at the national level to monitor the prevalence and the patterns of sexual violence within prison facilities, and therefore the extent of the problem is not precisely known.

The current study comes in a timely manner as the financial crisis and the long recession faced by the Greek economy, since 2008, has greatly affected the conditions of many correctional facilities, while at the same time the number of incoming prisoners have surpassed the governments' ability to manage the new demands. According to the figures of the Council of Europe, overcrowding in Greek prisons has been the worst in EU, with the prison density per 100 places (prisoners in relation to places 
available) being the highest in the EU [25]. At the same time, the European Court of Human Rights identified three cases of inmates suffering poor detention conditions in Greek prisons in breach of the European Convention on Human Rights [26].

Likewise, the Council of Europe's Committee for the Prevention of Torture and Inhuman or Degrading Treatment or Punishment (CPT) in its biannual reports identified a disastrous situation in many areas of the prison system. The 2012 report published upon the Committee's visit on September 2011 [27], showed Greek prisons overcrowded at 151.7 percent capacity and a number of shortcomings in the Greek prison system (http://www.cpt.coe.int/documents/grc/2012-01-inf-eng.pdf). The situation, since 2011, has showed no improvement. The next report [28] published upon the Committee's visit on April 2013 noted that overcrowding was not efficiently addressed, since most of the prisons still operated at $200 \%$ to $300 \%$ of their capacity with lack of hygiene and medical screening upon admission, as well as with a shortage of health-care staff (http://www.cpt.coe.int/documents/grc/2014-10-16-eng.htm). Lack of prison staff was emphasized as impeding any effort to monitor prisoners and prevent the violent assaults against vulnerable groups of prisoners.

What is more alarming is the fact that the CPT Committee, both in 2014 and 2016, identified serious deficits in the process of interrogation and the investigation of allegations for ill-treatment and repeatedly recommended a proper internal complaints system accessible at any moment, being confidential, followed by formal investigation, and keeping the prisoner in informed of actions taken (CPT Report March 2016; https://rm.coe.int/168069667e). Despite the Greek Authorities' compliance with the recommendations of the European Committee and the promising measures taken to tackle this problem, there is still uncertainty about the enforcement and the sustainability of these measures in Greece during this critical period of economic crisis. The staff shortages and the salary cuts have severely affected the quality of prison services and the budget cuts have limited the possibility of improvements in prison life. The staff seem to lack rudimentary knowledge and techniques to efficiently cope with difficult situations, while their education has been oriented towards a punishment-based model rather than a model that emphasizes the detainees' integration and psychosocial adjustment. The latest visit of CPT to Greek prisons was conducted in 2019 to review the progress made by the Greek authorities since 2015 in relation to prison matters, but the report has not yet been published (https://www.coe.int/en/web/ cpt/-/council-of-europe-anti-torture-committee-visits-prisons-and-police-establishments-in-greece).

Under these circumstances and given the difficulty that has been noted of gaining access to prison populations [29], this study is expected to facilitate the initial assessment of the problem of inmate sexual violence, as well as offer important information for the design of large-scale surveys. Evidence from this study could also enable international comparisons of inmates' needs and the harmonization of future interventions.

\section{Materials and Methods}

\subsection{Sampling}

The largest prison in the country, housing approximately half of all the inmates of judicial prisons in the whole country (2000 out of 4500 in total) was selected out of 13 prison facilities that operate in Greece (Greek Ministry of Justice). Immigrants and illiterate inmates were excluded from the study to ensure that all the participants would have an adequate understanding of the study questionnaire. The prisoners' registry was used to identify the immigrants. The staff of the Social Service Department undertook the task of identifying the illiterate inmates based on personal data recorded during consultation with the inmates. A total of 400 inmates fulfilled all the above criteria and were eligible to participate in the study. All the eligible inmates were invited to participate in the study and received a sealed envelope containing an information sheet and a consent form, a questionnaire, and a postage envelope return addressed to the researchers. Informed consent was necessary prior to participation. The information sheet informed the participants about the study objectives and procedures, as well as about the option they had to withdraw from the study at any moment and receive psychological or 
emotional support, safely, in case they were overwhelmed by negative emotions due to recalling a traumatic experience. Participants returned the questionnaire completed in a sealed mailbox, which was circulated with confidentiality in the various prison sections by a prison social worker and an assistant. This particular social worker was assigned the role of intermediating between prisoners and the research team and had previously received structured guidance by members of the research team regarding their role to emerging queries regarding the nature of the study, as well as their response to alarming emotional reactions during the study implementation.

\subsection{Research Instrument}

This study used a self-administered questionnaire, which was developed on the basis of international literature $[30,31]$ and was completed anonymously. The questionnaire elicited information on sociodemographic and offence-related characteristics, as well as on the participants' experiences of sexual coercion by an inmate during their incarceration. Two individual questions, with "yes/no" response option, were used to measure sexual victimization during the current incarceration ("Since the time you have been incarcerated in this facility has any of your inmates attempted to kiss or touch any part of your body in a sexually offensive way against your will (touching of genitals, etc.)?" and "Since the time you have been incarcerated in this facility has any of your inmates forced you to a sexual intercourse against your will (oral or anal sex)?"). A positive response to at least one of the two questions implied sexual victimization by an inmate during the current incarceration. Witnessing the sexual coercion of another inmate during the current incarceration was measured through the question "Since the time you have been admitted in this facility have you witnessed an inmate's sexual coercion?" with yes/no response option. Participants' sexual victimization during childhood was captured through a set of six questions with yes/no response option (Did you experience any of the following situations by an individual at least 5 years older than you, when you were 16 years old or younger, which were conducted in a sexual way and were not part of age-appropriate family/parenting interactions? (a) hugs/kisses in a sexual way; (b) display of genitals; (c) touching body parts; (d) touching genitals; (e) attempted anal contact; (f) completed anal contact). A positive response to at least one of the six questions implied sexual victimization during childhood. Participants were further asked to select their preferred response strategies (yes/no option) in a potential sexual victimization among a list of 11 strategies (e.g., violent reaction, disclosure to prison guard, request for cell transfer, do nothing). Lastly, participants' self-esteem was measured through the Rosenberg Self-Esteem Scale [32]. This particular scale has previously demonstrated high reliability in a Greek sample [33,34]. The scale measures the positive or negative view of oneself through 10 individual items. Participants are asked to indicate the extent of their agreement or disagreement with these 10 items on a 4-point scale anchoring from 1 (strongly disagree) to 4 (strongly agree).

\section{Results}

A total of 50 individuals returned the questionnaire completed out of the 400 individuals that received the questionnaire.

\subsection{Participants' Sociodemographic Characteristics}

Participants had a mean age of 33.0 years (SD $=8.9)$. Most of them were single $(n=28,56.0 \%)$, heterosexual $(n=38,76.0 \%)$, graduates of senior high school $(n=30,60.0 \%)$, salaried prior to incarceration $(n=22,44.0 \%)$, and more than half of them had no past penalties ( $n=30,60.0 \%)$ (Table 1$)$. 
Table 1. Participants' sociodemographic and offence-related characteristics.

\begin{tabular}{|c|c|c|}
\hline$n=50$ & $n$ & $\%$ \\
\hline Age * & 33.0 & 8.9 \\
\hline \multicolumn{3}{|c|}{ Family status } \\
\hline Married & 10 & 20.0 \\
\hline Single & 28 & 56.0 \\
\hline In separation & 6 & 12.0 \\
\hline Divorced & 5 & 10.0 \\
\hline Widow & 1 & 2.0 \\
\hline \multicolumn{3}{|c|}{ Educational level } \\
\hline Primary school & 6 & 12.0 \\
\hline Junior high school & 8 & 16.0 \\
\hline Senior high school & 30 & 60.0 \\
\hline Higher education & 6 & 12.0 \\
\hline \multicolumn{3}{|c|}{ Occupation } \\
\hline Salaried & 22 & 44.0 \\
\hline Self-employed & 13 & 26.0 \\
\hline Unemployed & 9 & 18.0 \\
\hline Other & 6 & 12.0 \\
\hline \multicolumn{3}{|c|}{ Sexual orientation } \\
\hline Homosexual & 4 & 8.0 \\
\hline Heterosexual & 38 & 76.0 \\
\hline Bisexual & 8 & 16.0 \\
\hline \multicolumn{3}{|c|}{ Past conviction } \\
\hline No past conviction & 30 & 60.0 \\
\hline Past conviction for same offence & 13 & 26.0 \\
\hline Past conviction for other offence & 7 & 14.0 \\
\hline
\end{tabular}

${ }^{*}$ Mean, Standard Deviation.

\subsection{Experiences of Sexual Victimization}

A total of thirteen participants $(26.0 \%)$ were sexually victimized during incarceration as they responded positively to at least one of the two relevant questions. Out of the 13 sexually victimized participants, a total of five participants ( $38.5 \%$ ) experienced only non-penetrative sexual victimization (admitted that an inmate attempted to touch them in a sexually offensive way during their current incarceration), one participant $(7.7 \%)$ experienced only penetrative sexual victimization (forced by an inmate to have oral or anal sexual contact against their will), and seven participants (53.8\%) experienced both types of sexual victimization. Detailed information on the experiences of sexual victimization is provided in Tables 2-5. 
Table 2. Personal characteristics of the study participants.

\begin{tabular}{|c|c|c|c|c|c|}
\hline \multirow[b]{2}{*}{ Personal Information } & \multirow[b]{2}{*}{$\begin{array}{l}\text { No Victimization } \\
\qquad(n=37)\end{array}$} & \multirow[b]{2}{*}{$\begin{array}{l}\text { Victimization } \\
\quad(n=13)\end{array}$} & \multicolumn{3}{|c|}{ Sexually Victimized $(n=13)$} \\
\hline & & & $\begin{array}{c}\text { Only Non } \\
\text { Penetrative Sexual } \\
\text { Victimization }(n=5)\end{array}$ & $\begin{array}{c}\text { Only Penetrative } \\
\text { Sexual } \\
\text { Victimization }(n=1)\end{array}$ & $\begin{array}{c}\text { Both Penetrative and } \\
\text { Non-Penetrative }(n=7)\end{array}$ \\
\hline \multicolumn{6}{|c|}{ Family status } \\
\hline Single & 21 (56.7) & $7(53.8)$ & $2(40.0)$ & - & 5 (71.4) \\
\hline Divorced & $2(5.4)$ & $3(23.1)$ & $1(20.0)$ & - & $2(28.6)$ \\
\hline Widow & $1(2.7)$ & $0(0.0)$ & $0(0.0)$ & - & $0(0.0)$ \\
\hline \multicolumn{6}{|c|}{ Educational level } \\
\hline Primary & $5(13.5)$ & $0(0.0)$ & $0(0.0)$ & - & $0(0.0)$ \\
\hline Junior high school & $5(13.5)$ & $4(30.8)$ & $0(0.0)$ & - & $3(42.8)$ \\
\hline Self-employed & $11(29.7)$ & $2(15.4)$ & $1(20.0)$ & - & $1(14.2)$ \\
\hline Unemployed & $4(10.8)$ & $5(38.4)$ & $2(40.0)$ & - & $2(28.8)$ \\
\hline Other & $3(8.2)$ & $3(23.1)$ & $2(40.0)$ & - & $1(14.2)$ \\
\hline \multicolumn{6}{|c|}{ Sexual orientation } \\
\hline Homosexual & $0(0.0)$ & $4(30.8)$ & $1(20.0)$ & - & $2(28.6)$ \\
\hline Heterosexual & $33(89.2)$ & $5(38.4)$ & $2(40.0)$ & - & $3(42.8)$ \\
\hline Bisexual & $4(10.8)$ & $4(30.8)$ & $2(40.0)$ & - & $2(28.6)$ \\
\hline \multicolumn{6}{|c|}{ Self-esteem * } \\
\hline & $28.2(4.8)$ & $27.3(2.1)$ & $28.2(1.7)$ & $32.0(\mathrm{~N} / \mathrm{A})$ & $26.1(1.0)$ \\
\hline
\end{tabular}

* Mean, Standard Deviation.

Table 3. Offence-related characteristics of the study participants.

\begin{tabular}{|c|c|c|c|c|c|}
\hline \multirow[b]{2}{*}{$\begin{array}{l}\text { Offence-Related } \\
\text { Information }\end{array}$} & \multirow[b]{2}{*}{$\begin{array}{l}\text { No Victimization } \\
\quad(n=37)\end{array}$} & \multirow[b]{2}{*}{$\begin{array}{l}\text { Victimization } \\
\quad(n=13)\end{array}$} & \multicolumn{3}{|c|}{ Sexually Victimized $(n=13)$} \\
\hline & & & $\begin{array}{c}\text { Only Non } \\
\text { Penetrative Sexual } \\
\text { Victimization }(n=5)\end{array}$ & $\begin{array}{c}\text { Only Penetrative } \\
\text { Sexual } \\
\text { Victimization }(n=1)\end{array}$ & $\begin{array}{c}\text { Both Penetrative and } \\
\text { Non-Penetrative }(n=7)\end{array}$ \\
\hline \multicolumn{6}{|c|}{ Past conviction } \\
\hline No & $28(75.7)$ & $2(15.4)$ & $0(0.0)$ & - & 2 (28.6) \\
\hline Yes, same offence & $7(18.9)$ & $6(46.1)$ & $2(40.0)$ & $1(100.0)$ & $3(42.8)$ \\
\hline Yes, other offence & $2(5.4)$ & $5(38.5)$ & $3(60.0)$ & - & $2(28.6)$ \\
\hline \multicolumn{6}{|c|}{ Current offence } \\
\hline Robbery & $5(13.5)$ & $4(30.8)$ & $1(20.0)$ & - & $3(42.8)$ \\
\hline Theft & $3(8.0)$ & $0(0.0)$ & $0(0.0)$ & - & $0(0.0)$ \\
\hline Homicide & $5(13.5)$ & $1(7.7)$ & $1(20.0)$ & - & $0(0.0)$ \\
\hline Debts & $2(5.4)$ & $0(0.0)$ & $0(0.0)$ & - & $0(0.0)$ \\
\hline Drugs & $18(48.6)$ & $3(23.0)$ & $2(40.0)$ & - & $1(14.2)$ \\
\hline Rape/lewdness & $0(0.0)$ & $1(7.7)$ & $0(0.0)$ & - & $1(14.2)$ \\
\hline Bawdiness & $1(2.7)$ & $0(0.0)$ & $0(0.0)$ & - & $0(0.0)$ \\
\hline Pedophilia & $0(0.0)$ & $2(15.4)$ & $1(20.0)$ & - & $1(14.2)$ \\
\hline Pornography & $1(2.7)$ & $1(7.7)$ & $0(0.0)$ & $1(100.0)$ & $0(0.0)$ \\
\hline Other & $2(5.4)$ & $1(7.7)$ & $0(0.0)$ & - & $1(14.2)$ \\
\hline \multicolumn{6}{|c|}{ Sentence duration } \\
\hline Life imprisonment & $2(5.4)$ & $1(7.7)$ & $1(20.0)$ & $0(0.0)$ & $0(0.0)$ \\
\hline 5-20 years & $10(27.0)$ & $9(69.3)$ & $3(60.0)$ & $1(100.0)$ & $5(71.4)$ \\
\hline 10 days -5 years & $12(32.4)$ & $3(23.0)$ & $1(20.0)$ & $0(0.0)$ & $2(28.6)$ \\
\hline 1 day-1 month & $5(13.5)$ & $0(0.0)$ & $0(0.0)$ & $0(0.0)$ & $0(0.0)$ \\
\hline Pre-trial detention & $1(2.7)$ & $0(0.0)$ & $0(0.0)$ & $0(0.0)$ & $0(0.0)$ \\
\hline
\end{tabular}


Table 4. Strategies preferred by the study participants in response to potential sexual victimization in prison.

\begin{tabular}{|c|c|c|c|c|c|}
\hline \multirow[b]{2}{*}{ Response Strategies } & \multirow[b]{2}{*}{$\begin{array}{l}\text { No Victimization } \\
\quad(n=37)\end{array}$} & \multirow[b]{2}{*}{$\begin{array}{l}\text { Victimization } \\
\quad(n=13)\end{array}$} & \multicolumn{3}{|c|}{ Sexually Victimized $(n=13)$} \\
\hline & & & $\begin{array}{c}\text { Only Non } \\
\text { Penetrative Sexual } \\
\text { Victimization }(n=5)\end{array}$ & $\begin{array}{c}\text { Only Penetrative } \\
\text { Sexual } \\
\text { Victimization }(n=1)\end{array}$ & $\begin{array}{c}\text { Both Penetrative and } \\
\text { Non-Penetrative }(n=7)\end{array}$ \\
\hline Violent reaction & $18(48.6)$ & $9(69.3)$ & $4(80.0)$ & - & $5(71.4)$ \\
\hline Disclosure to co-mate & $9(24.3)$ & $5(38.5)$ & $2(40.0)$ & 1 & $2(28.6)$ \\
\hline Disclosure to friends & $6(16.2)$ & $5(38.5)$ & $2(40.0)$ & 1 & $2(28.6)$ \\
\hline Disclosure to head officer & $6(16.2)$ & $4(30.8)$ & $2(40.0)$ & 1 & $1(14.2)$ \\
\hline Disclosure to prison guard & $6(16.2)$ & $2(15.4)$ & $0(0.0)$ & 1 & $1(14.2)$ \\
\hline $\begin{array}{l}\text { Disclosure to prison service } \\
\text { providers (e.g., doctor) }\end{array}$ & $8(21.6)$ & $2(15.4)$ & $0(0.0)$ & 1 & $1(14.2)$ \\
\hline
\end{tabular}

Table 5. Other sexual victimization experiences of the study participants.

\begin{tabular}{|c|c|c|c|c|c|}
\hline \multirow[b]{2}{*}{ Past Sexual Victimization } & \multirow[b]{2}{*}{$\begin{array}{l}\text { No Victimization } \\
\quad(n=37)\end{array}$} & \multirow[b]{2}{*}{$\begin{array}{l}\text { Victimization } \\
\quad(n=13)\end{array}$} & \multicolumn{3}{|c|}{ Sexually Victimized $(n=13)$} \\
\hline & & & $\begin{array}{c}\text { Only Non } \\
\text { Penetrative Sexual } \\
\text { Victimization }(n=5)\end{array}$ & $\begin{array}{c}\text { Only Penetrative } \\
\text { Sexual } \\
\text { Victimization }(n=1) \\
\end{array}$ & $\begin{array}{l}\text { Both Penetrative and } \\
\text { Non-Penetrative }(n=7)\end{array}$ \\
\hline \multicolumn{6}{|c|}{$\begin{array}{c}\text { Childhood sexual victimization }(<16 \text { years) } \\
\text { (situations not part of age-appropriate family/parenting interactions) }\end{array}$} \\
\hline Hugs & $9(24.3)$ & $8(61.5)$ & $2(40.0)$ & 1 & $5(71.4)$ \\
\hline Display of genitals & $5(13.5)$ & $2(15.4)$ & $1(20.0)$ & - & $1(14.2)$ \\
\hline Petting & $9(24.3)$ & $9(69.3)$ & $2(40.0)$ & 1 & $6(85.7)$ \\
\hline Touching genitals & $7(18.9)$ & $5(38.5)$ & $1(20.0)$ & 1 & $3(42.8)$ \\
\hline Attempted anal sex & $3(8.1)$ & $4(30.8)$ & $2(40.0)$ & - & $2(28.6)$ \\
\hline Completed anal sex & $2(5.4)$ & $4(30.8)$ & $1(20.0)$ & - & $3(42.8)$ \\
\hline $\begin{array}{c}\text { Total Child sexual } \\
\text { victimization (Mean/SD) }\end{array}$ & $1.2(1.9)$ & $2.5(2.0)$ & $1.8(2.4)$ & $3.0(\mathrm{~N} / \mathrm{A})$ & $3.0(1.8)$ \\
\hline \multicolumn{6}{|c|}{ Witness inmate's sexual victimization } \\
\hline Yes & $7(18.9)$ & $13(100.0)$ & $5(100.0)$ & $1(100.0)$ & $7(100.0)$ \\
\hline
\end{tabular}

\subsection{Victims' Profile}

Participants who reported only non-penetrative victimization $(n=5)$ had a mean age of 32.0 years (SD7.56), were mostly single (40.0\%) and unemployed (40.0\%), graduates of senior high school $(100.0 \%)$, and many of them were heterosexual and bisexual ( $40.0 \%$ each). The majority of them were currently sentenced for five to 20 years $(69.3 \%)$, many of them were convicted for drugs $(40.0 \%)$, and most of them had a past conviction for other offences $(60.0 \%)$. All of them had witnessed another inmate's sexual victimization during their current incarceration. They had a total score of 1.8 (SD2.4) in child sexual victimization and their self-esteem had an average of 28.2 (SD1.7). Most of them would prefer to react violently and retaliate in response to a potential sexual victimization $(80.0 \%)$.

There was only one participant who reported only penetrative victimization was currently sentenced for five to 20 years for pornography and had past convictions for the same offences. He had witnessed another inmate's sexual victimization during his current incarceration. He had a total score of 3.0 in child sexual victimization, and he scored 32.0 in the self-esteem scale. In a potential sexual victimization, he would prefer to disclose his experience to commutes and friends, as well as to various prison authorities.

Lastly, participants who reported both types of sexual victimization $(n=7)$ had a mean age of 30.2 years (SD8.3) and most of them were single (71.4\%). Many of them were graduates of junior high school $(42.8 \%)$, salaried prior to incarceration $(42.8 \%)$, or unemployed $(28.8 \%)$, and most of them 
were heterosexual (42.8\%), followed by homosexual and bisexual ( $28.8 \%$ each). Many of them were currently sentenced for five to 20 years $(71.4 \%)$, many of them were convicted for robbery $(42.8 \%)$, and most of them had a past conviction for the same offences $(42.8 \%)$. All of them had witnessed another inmate's sexual victimization during their current incarceration. They had a total score of 3.0 (SD1.8) in child sexual victimization and their self-esteem had an average of 26.1 (SD1.0). The vast majority of them would prefer to react violently and retaliate, as well as request a transfer to another cell in response to a potential sexual victimization (71.4\% each). Detailed information on the victims profile is provided in Tables $2-5$.

\subsection{Comparison between the Victimized and the Non-Victimized Participants}

Victims of sexual violence were younger in age and had a lower self-esteem as compared with those not victimized. The single and divorced, the graduates of senior high school followed by those of junior high school, the unemployed prior to incarceration, as well as the homosexuals and bisexuals were overrepresented among the victimized participants. On the contrary, the non-victimized participants were mostly single, followed by married, salaried, graduates of senior high school, and heterosexual (Table 2). As regards to offence-related characteristics, those convicted in the past for different offences, those currently convicted for rape, pedophilia and pornography, and those with long sentences but not life imprisonment, were overrepresented among the victimized participants as compared with the non-victimized participants who were primarily those never convicted in the past, those currently convicted for drugs, and those with sentences less than five years (Table 3). The victimized participants were further shown to mostly prefer violent reactions and revenge as a response strategy to a potential sexual victimization as compared with the non-victimized participants who reported a higher preference for a cell transfer (Table 4). Lastly, as regards to other victimization experiences, persons who reported "attempted" or "completed" anal sex during childhood, as well as those who witnessed the victimization of other inmates, reported higher levels of victimization during incarceration as compared to those who had no similar experiences (Table 5).

\section{Discussion}

This is the first study that looked at the experiences of sexual victimization of incarcerated men in Greece. The small sample is a serious limitation of the study that needs to be acknowledged. Comparing key sociodemographic, offence- and sentence-related characteristics between our study participants and the 10-year average performance of the total population of Greek prisoners (http: //www.ministryofjustice.gr/site/en/Leadership/Greetings.aspx), there is evidence of representativeness in some aspects (e.g., $\sim 60.0 \%$ foreigners in total vs. $80.0 \%$ foreigners excluded from our sample based on the inclusion criteria (peak in 2011 with $72.2 \%$ of foreigner detainees in the largest prison), $23.0 \%$ of prisoners with one month to five years imprisonment vs. $30.0 \%$ in our sample, $\sim 8.0 \%$ of prisoners with life imprisonment vs. $6.0 \%$ in our sample, $32.0 \%$ of prisoners with drug-related violations vs. $52.0 \%$ in our sample), while there seems to be over- or underrepresentation in some other aspects (e.g., $29.0 \%$ of prisoners in pre-trial detention vs. $2.0 \%$ in our sample and $0.3 \%$ of prisoners with debt-related violations vs. $4.0 \%$ in our sample).

In view of the above, generalizability of the study findings to the general population of Greek prisoners should be made with caution since the study had a low response rate and lacked evidence on whether the respondents differed significantly from non-respondents in terms of sexual victimization or other important risk factors. For example, the low response rate among prisoners in pretrial detention needs to be taken into consideration when interpreting the study findings, as international literature identifies them as a high-risk group for sexual victimization in prisons and our findings probably underestimate their experiences. Further to this consideration, it is worth mentioning that population-based studies (e.g., BJS, NIS-3, and SHAAP) [19] tend to report low prevalence rates (between $3 \%$ and $10 \%$ ), while studies with small sample sizes or non-random sampling designs tend to report much higher prevalence figures ( $>25 \%$ ) [12]. Most importantly, research employing expansive 
definitions of sexual misconduct reveal much higher prevalence rates as compared with those focusing on completed rape. Given these methodological considerations, we should identify the possibility of overestimated figures among our study findings.

Despite this limitation, this study has attempted to begin to fill the gap in our understanding of sexual abuse within prison facilities, which is considered to be a field where data and information is still scarce worldwide, due to the limited access in prison facilities $[14,19]$. Therefore, very little research has focused on prisoners $[35,36]$. What is evident from this very initial assessment of the problem is the fact that sexual assault is a problem for inmates in Greek prisons.

What seems important in the results is the fact that approximately one quarter of the inmates $(26.0 \%)$ in our study were sexually assaulted by another inmate. This is consistent with previous research in male inmates in U.S., which indicated that $21 \%$ to $22 \%$ of prisoners had been subjected to sexual pressure or assault at least once $[14,37]$. It is, however, expected that this percentage underestimates the problem as sexual assault in prison facilities is underreported [35,38-40]. In general, the phenomenon has been said to be on the rise over the last few decades due to three major interrelated factors which include: (a) the distinct manifestations of the prison social order; (b) the correction officers' role in policing; and (c) the overcrowding [41]. These factors may be better understood with the assistance of the deprivation model, which suggests that aggressive behavior among inmates is triggered by the painful experiences inside the prisons [42].

Although our study did not generate evidence on the contribution of contextual factors in sexual misconduct, there are several institutional aspects in our study setting, which could assist us in the interpretation of our findings regarding sexual misconduct. More specifically, this particular prison facility has been shown in various CPT and Ombudsman reports to accommodate four, or even five inmates in $9.5 \mathrm{~m}^{2}$ cells, resulting in less than $2 \mathrm{~m}^{2}$ space available for each individual prisoner, and sometimes with one prisoner of the five sleeping on the floor [43]. In fact, overcrowding and chronic shortage of staff seems to persist in the Greek prison system, as shown in the latest CPT report (March 2016; https://rm.coe.int/168069667e). In addition to the above, the staff has been criticized for spending little time in the accommodation areas leaving prisoners unprotected. As a result, prisoners have been shown to have no trust in the management to resolve questions of intimidation and violence (CPT Report March 2016, https://rm.coe.int/168069667e).

Apart from the deprivation model, this study offers a lot of insight into potential links to the importation model, which argues that prison violence is performed by individuals, who were dysfunctional prior to incarceration [44,45]. What becomes clear from the results of this study, which may find support in the importation model, is the fact that the inmates who experienced sexual victimization seem to have certain individual characteristics that may render them vulnerable to sexual victimization in prison. For example, although the small sample size in this study did not allow us to carry out a more rigorous statistical analysis, the unemployed were shown to experience sexual victimization at a higher level than other inmates. This is not surprising under the perspective of the deprivation model, as prior unemployment is probably one aspect of an overall vulnerable profile, linked with poverty and social exclusion. This could imply that an individual leading such a profile before incarceration is considered to be vulnerable in different social contexts [44].

Likewise, the results of this study indicated that participants with a homosexual or bisexual sexual orientation experienced more sexual approaches or assaults from those reporting a heterosexual sexual orientation. In line with our finding, previous research has shown a link between sexual victimization during incarceration and sexual orientation $[17,19,30,41,46]$. It has been suggested that "straight" males sexually assault individuals with a non-heterosexual orientation because they consider them to be subordinate and they expect them to be submissive [47]. Likewise, in BJS surveys 2011 to 2012, non-heterosexual inmates were among the most vulnerable for sexual victimization. In 2008, the first U.S. National Former Prisoner Survey (NFPS) found 34\% of bisexual males, and 39.0\% of homosexual or gay males to have been sexually victimized by an inmate as compared to $3.5 \%$ of heterosexual males [17]. In line with this, the Special Rapporteur on Torture to the Human Rights Council identified 
this high vulnerability of non-heterosexual inmates many years ago [48] with transgender persons, especially male-to-female transgender inmates, considered to be at great risk in male prisons. However, it should be noted, that heterosexual men are less likely to report victimization due to feelings of shame, and therefore possibly resulting in the overestimation of the phenomenon among non-heterosexual men [19].

Interestingly, the victimized participants in this study were shown to have past convictions for the same or different offences than those related to their current incarceration, and long duration of sentences. Nevertheless, research has consistently shown that first-time offenders are more often the targets of sexual assaults due to being unaccustomed to the prison subculture, and therefore more vulnerable to intimidation [49,50]. The first population survey in Australia prisoners generated evidence in support of our findings, suggesting that sexual victimization is more likely to occur among first time offenders and those who had been in prison for a period exceeding five years than among other groups [19], however, this needs to be examined together with the information on the current offence. In particular, this study indicated that those who were currently convicted for robbery and drugs were overrepresented among the victimized participants. On the basis of the importation model, it is interesting to find that most of the victimized prisoners are serving time for nonviolent offences, but to survive behind bars, they are forced to adapt to the culture of brutality [44,45].

Not surprisingly, our study identified that sexual abuse in childhood was a characteristic more evident among the participants that were victimized as compared to those who were not. This is another common measure of the importation model, examined very often as part of the history of violence to assist in the estimation of risk scores [44]. Its contribution as a risk factor to the interpretation of sexual victimization has been clearly demonstrated in recent literature [18]. This could probably be attributed to problematic adaptive emotion regulation abilities, which decrease individuals' recognition of impending danger or make their vulnerability more visible to perpetrators. Past research has also found two to five times increased likelihood of victimization among those who had similar experiences prior to age 18 as compared with their counterparts [51]. The multiple victimization could potentially explain the levels of self-esteem, which were found to be lower in the victimized participants as compared with the non-victimized ones. Low self-esteem has long been shown as a major psychological aftermath for sexual violence victims, which has often been considered to be a manifestation of underlying anger [52].

What is thought to be more alarming in this study, is the fact that all the inmates who were sexually victimized reported witnessing other inmates' sexual coercion. In fact, this may imply that sexual misconduct is well-known but underreported. It has been noted that it is common for inmates to avoid reporting witnessing the victimization of others out of fear of violating the convict law, fear of being the targets of retaliation, or even fear of involving correctional officers in prisoners' matters [53-55]. Past research found $25.0 \%$ of victimized prisoners avoid reporting their victimization as they believed it would make no difference and $20.0 \%$ did the same out of fear of retaliation [56]. Other research has offered support for this finding [34]. Interestingly, while prisoners seem to support the idea of reporting such experiences, very few are likely to report their own victimization [56]. Male rape myths have been thought to highly contribute to underreporting of male sexual victimization, since they suggest that only gay men become victims due to being unable to defend themselves like "real men" do. The stigma attached to prison rape, the feelings of shame and the humiliating reporting process are some more reasons explaining why some prisoners remain quiet [57-59]. Low literacy level and education has also been noted as a factor impeding reporting and resulting in victims' low understanding of prison policies and legal procedures [60]. Interestingly, from our study, it becomes apparent that tools currently available in Greek prisons are not employed by the target group. More precisely, the Office of the Secretary General for Counter-Criminal Policy in Greece operates a hotline for complaints by inmates regarding their detention conditions, and offers a standardized "Information Booklet for the prisoners' rights" (Form A-33) together with a complaints form called "Complaints filed by detainees"(D-34), in a language that inmates understand, to file a complaint on any poor detention conditions, abuse, 
ill-treatment or other violations of rights and address it to any Authority they wish. Further to this, a senior Police Officer has been appointed by the General Police Directors to control and supervise the services involved in these matters (http://www.cpt.coe.int/documents/grc/2014-27-inf-eng.pdf). Despite these efforts made by the Greek Ministry of Justice, sexual violence among inmates is still a prevalent and greatly underreported problem in Greek prisons.

Further to the aforementioned, the evidence on the preferred response strategies, which was produced from this study is in line with the existing literature. More precisely, the victimized participants in our study reported that they would mostly prefer a violent reaction as a response to sexual victimization, which was not the case for the non-victimized participants, who preferred a more indirect way to respond. This probably derives from the experience of victimization and their need to retaliate. In support of this, it has been suggested that this is part of the victims' effort to prove that they can manage their own matters like "real" men. Physical retaliation could be seen also as a masculine response aimed to make it clear to others that they are not sexually interested in other men [9].

Another issue of outmost importance, is the fact that participants who experienced both types of sexual victimization (penetrative and non-penetrative) have been shown in this study to have worse performance both in child sexual victimization and self-esteem scores, as compared with those who experienced only non-penetrative victimization and those who were not victimized at all. Many of them were also found to have low educational level, shorter sentences (10 days to five years) primarily for non-violent offences, and no past convictions, which may all be indicative of an increased vulnerability. Nevertheless, we should note that despite the fact that most of the information retrieved through the current study is in line with the existing literature on the subject, it cannot be expected to provide reliable estimations on the actual size of the problem, especially among the subcategories of the victimized participants, which were underrepresented.

\subsection{Current Challenges and Future Perspectives in Addressing Sexual Violence within Prison}

On the basis of the results of our study, we urgently recommend to the Greek Authorities to consider this public health issue. Certain measures and interventions could be undertaken to protect those who seem to be at risk, as well as treat those who have been affected. More precisely, our study suggests that inmates with maltreatment histories in childhood, as well as inmates with lower self-esteem, are more vulnerable to sexual victimization. This evidence could be translated into certain interventions. For example, incorporating questions regarding maltreatment histories within the initial assessment of prisoners' mental health status could potentially serve as a process of early identification of signs of vulnerability that could result in higher attention paid to individuals at risk by the prison social and mental health care staff. Assessing the level of prisoners' self-esteem and designing certain individual or group interventions to improve feelings of low self-worth, could also constitute an effective measure towards the prevention of sexual victimization and re-victimization.

Our study further suggests that LGBT inmates are more vulnerable to sexual assaults. It seems, thus, important to undertake measures in the sphere of prison life to protect them, including but not limited to housing arrangements, individual showering, etc. Most importantly, it seems urgent to tackle the discrimination and stigma that LGBT people face in prison and undertake action to promote respectful relationships among prisoners, as well as improve the staff's cultural competency at correctional settings across Greece.

Our study also suggests that sexual assaults in prison are highly visible, although not disclosed. In fact, a large number of prisoners in the current study reported witnessing the victimization of other inmates, which implies that peers probably know but prefer to keep silent. Further to the aforementioned, our study indicates that victimized inmates prefer violent reactions as a means of retaliation and this in turn implies that sexual assaults may generate follow-up violent acts. It seems, thus, important both for the victims of sexual assault and for their peers, to be given multiple avenues to make confidential complaints, which should be thoroughly investigated, and the results fully communicated to complainants. Educating prisoners on formal reporting pathways, offering 
opportunities to report acts of retaliation, as well as providing access to advocates outside the prison system would be effective interventions in facilitating disclosure. Interventions could also target peers, friends, and family members of those who are incarcerated, who may be aware of the problem.

Future policy in Greece should aim at transforming Greek correctional settings into trauma-informed settings by setting practice standards for the prevention and early intervention to trauma among the population of prisoners, including the "Do no harm" approach, strategies for the minimization of re-traumatization, predictable and consistent limits, and staff training in responding to trauma/trauma symptoms [61,62]. Improving interpersonal functioning through effective interventions on emotion regulation would help inmates regulate negative mood states and avoid maladaptive strategies (e.g., alcohol). Individual or group cognitive behavioral therapy should be considered because it has been widely identified as the best practice for treating post-traumatic stress in trauma survivors. Future policy in Greece should also consider good practice and lessons learned from implementation of relevant policies within the correctional system of other countries. The Skills Training in Affective \& Interpersonal Regulation program (STAIR) [63], is an emotion-focused treatment program for survivors of sexual abuse [64]. The "Trauma Affect Regulation: Guide for Education and Treatment" (TARGET) and the "Seeking Safety" have been developed to assist victimized individuals to understand trauma and control their emotional response [63]. Prison Rape Elimination Act (PREA) is also an ambitious piece of legislation, which could offer much to Greek policymakers, despite the conflicting evaluation outcomes and the severe criticism for low enforcement in the USA [65]. In fact, PREA aimed to sanction prison sexual violence through introducing a set of tools (e.g., technical assistance, grants, and standards). Within the PREA framework [66,67], all states in the U.S. undertook various tasks such as training of the staff and offenders, improvement or development of investigative structures, development of data collection capacities, enhancement of security by installing cameras, and development of housing options for victims. Other well-established initiatives in Europe could also provide useful insight into effective prison violence prevention, including situational measures (e.g., improved supervision) offender programs (e.g., therapeutic communities and education programs), and other "social prevention" programs [10].

\subsection{Study Limitations}

This study had limitations that should be acknowledged. One limitation is related to the small sample size, which precluded us from conducting more sophisticated statistical analyses that could have further aided in our understanding of the characteristics of male victims. Furthermore, the prevalence of sexual victimization estimated in our study seems to be similar with the ones reported in other studies, however, questions remain on whether we have captured the actual size of the problem.

Our sample did not include immigrants, who represent a great part of the population of inmates and whose human rights are thought to be highly violated. In fact, according to the Hellenic League of Human Rights report, there have been cases of foreign detainees with low awareness of their rights, and therefore have limited access to interpretation services and legal assistance. This highlights the need to consider the additional vulnerabilities that may be affecting those excluded from this study in order to assure that their health and human rights are protected too, especially in terms of sexual victimization. However, carrying out research with this population requires large-scale study design and a culturally sensitive approach.

Furthermore, our sample was derived from one male prison facility, and thus the results cannot be generalized or assumed to be representative of the total population of male inmates. Moreover, a high number of inmates declined to participate in the study, which may be an important confound, as we do not know how the inmates who chose not to take part in the study differed in their experiences from those who did participate. Although reminders were sent by the research team at monthly intervals, the response rate only slightly increased. There is a possibility that inmates were not convinced by the guarantees of confidentiality and this may have influenced the response rate. However, this is not surprising since high refusal rates have been reported in most studies of inmates. 
Last but not least, we need to acknowledge the fact that this study used a narrow definition of sexual misconduct and relied on participants' understanding of two single questions regarding sexual victimization. It would have been more effective to introduce follow-up questions to be able to identify the characteristics of the victimization (e.g., type and nature), in order to avoid potentially overestimated instances of certain types of sexual misconduct.

\section{Conclusions}

Findings from this research offer an initial assessment of the problem in a country with limited information and clear policy implications, which could be used to guide large-scale surveys to improve life in prison facilities. Most importantly, vulnerable groups identified in this small sample of inmates could receive further attention in future studies and policy initiatives. Profiling victims is expected to be useful for inmates' and staff's education regarding sexual violence in prison. Furthermore, this study underlined the need to commence large-scale studies in order to obtain a reliable baseline of incidence data, as well as the need to include macro-level and structural factors in future investigations to better understand the causes of this highly prevalent phenomenon. In fact, there are additional individual and contextual aspects with potential links to sexual victimization, which were not captured in this study and should be addressed in future research. For example, as previous research suggests that the risk is greatest in the first 6 months of admittance to a correctional facility [68,69], the results would have been more informative, if participants were asked to indicate when their victimization occurred during the present incarceration. It would be further interesting to investigate sexual victimization among more diverse populations of prisoners and correctional institutions, as well as in female facilities. Revisiting the correctional sites and carrying out follow-up surveys is missing from research in correctional settings, although considered to be very important. Furthermore, future research needs to consider victimization from staff, which has been shown to be very prevalent in male prisons and was not captured in this study. Most importantly, the study stresses the need to introduce mechanisms to better monitor the problem in Greek prisons for the prison authorities to intervene in a timely manner. Further to that, measures taken in response to the problem, should not single out those at risk while overlooking other important parameters such as the potential institutional and social factors that might create the problem. Last but not least, given the fact of underreporting to correctional staff, policymakers should consider the active involvement of external organizations, such as community-based services and prisoner support groups, in the prevention of violence and the treatment of trauma [19].

Author Contributions: Conceptualization, M.P., M.G., and J.C.; methodology, M.P., A.T.; D.P., and J.C.; validation, M.P., A.T., and D.P.; formal analysis, M.P., A.T., D.P., and J.C.; investigation, M.P. and M.G.; data curation, M.P. and M.G.; writing—original draft preparation, M.P.; writing—review and editing, M.P., A.T., D.P., M.G., and J.C.; supervision, M.P.; project administration, M.G.

Funding: This research received no external funding.

Acknowledgments: Ethical approval for this project was granted by the Greek Ministry of Justice (reference no. 4161) and the prison council (reference No. 616).

Conflicts of Interest: The authors declare no conflict of interest.

\section{References}

1. Rights Watch Report 2001, US, Human Rights Developments. Available online: https://www.hrw.org/legacy/ wr2k1/usa/index.html (accessed on 10 October 2018).

2. O'Donnell, I. Prison rape in context. Br. J. Criminol. 2004, 44, 241-255. [CrossRef]

3. Moller, L.; Stover, H.; Jurgens, R.; Gatherer, A.; Nikogosian, H. (Eds.) Health in Prisons: A WHO Guide to the Essentials in Prison Health; World Health Organization Press: Copenhagen, Denmark, 2007.

4. Stevens, A. Coercive Sex in Prison; Howard League for Penal Reform Press: London, UK, 2014.

5. Kunzel, R. Criminal Intimacy: Prison and the Uneven History of Modern American Sexuality; University of Chicago Press: Chicago, IL, USA; London, UK, 2008. 
6. Wooden, W.S.; Parker, J. Men Behind Bars: Sexual Exploitation in Prison; Plenum Press: New York, NY, USA, 1982.

7. Connell, R.W. Masculinities, 2nd ed.; University of California Press: Berkeley, CA, USA, 2005.

8. Groth, A.N.; Burgess, A.W. Male rape: Offenders and victims. Am. J. Psychiatry 1980, 137, 806-810. [CrossRef] [PubMed]

9. Javaid, A. Male Rape in Law and the Courtroom. Available online: http://webjcli.org/article/view/340/434 (accessed on 3 September 2018).

10. Homel, R.; Thomson, C. Corrections Criminology. In Causes and Prevention of Violence in Prisons; O'Toole, S., Eyland, S., Eds.; Hawkins Press: Sydney, Australia, 2005; pp. 101-108.

11. Bottoms, A.E. Interpersonal Violence and Social Order in Prisons; Tonry, M., Petersilia, J., Eds.; The University of Chicago Press: Chicago, IL, USA, 1999; pp. 205-228.

12. Heilpern, D.M. Fear or Favour: Sexual Assault of Young Prisoners; Southern Cross University Press: Lismore, Australia, 1998.

13. Stemple, L. Male Rape and Human Rights. Hastings Law J. 2009, 60, 605-609.

14. Struckman-Johnson, C.; Struckman-Johnson, D.; Rucker, L.; Bumby, K.; Donaldson, S. Sexual coercion reported by men and women in prison. J. Sex Res. 1996, 33, 67-76. [CrossRef]

15. Beck, A.J.; Harrison, P.M. U.S. Dep't of Justice, Publ'n No. NCJ 221946, Sexual Victimization in State and Federal Prisons Reported by Inmates. 2007. Available online: http://www.ojp.usdoj.gov/bjs/pub/pdf/svljri07. pdf (accessed on 3 September 2018).

16. Beck, J.A.; Berzofsky, M.; Caspar, R.; Krebs, C. RTI International May 2013; NCJ 241399; U.S. Department of Justice, Office of Justice Programs, Bureau of Justice Statistics: Washington, DC, USA, 2013.

17. Beck, J.A.; Johnson, C. Publication Sexual Victimization Reported by Former State Prisoners, 2008; NCJ 237363; Part of the PREA Publications Series; U.S. Department of Justice, Office of Justice Programs, Bureau of Justice Statistics: Washington, DC, USA, 2012.

18. Caravaca-Sánchez, F.; Wolff, N. Understanding Polyvictimization in Prison: Prevalence and Predictors among Men Inmates in Spain. Available online: https://journals.sagepub.com/doi/abs/10.1177/0886260518775751? journalCode=jiva (accessed on 3 September 2019).

19. Simpson, P.L.; Reekie, J.; Butler, T.G.; Richters, J.; Yap, L.; Grant, L.; Richards, A.; Donovan, B. Factors Associated With Sexual Coercion in a Representative Sample of Men in Australian Prisons. Arch Sex Behav. 2016, 45, 1195-1205. [CrossRef]

20. Ahlin, E.M.; Hummer, D. Sexual victimization of juveniles incarcerated in jails and prisons: An exploratory study of prevalence and risk factors human. Vict. Offenders 2019, 14, 793-810. [CrossRef]

21. Optional protocol to the Convention against Torture and Other Cruel, Inhuman or degrading Treatment or punishment (“OpCaT”), G.a. Res. 57/199, U.n. doc. a/ReS/57/199 (Dec. 18, 2002). Available online: https://www.ohchr.org/EN/ProfessionalInterest/Pages/OPCAT.aspx (accessed on 1 February 2019).

22. International Covenant on Civil and political Rights, adopted dec. 16, 1966, 999 U.n.T.S. 171 (entered into force March 23, 1976). Available online: https:/treaties.un.org/doc/publication/unts/volume\%20999/volume999-i-14668-english.pdf (accessed on 1 February 2019).

23. Giotakos, O.; Markianos, M.; Vaidakis, N.; Christodoulou, G.N. Aggression, impulsivity, plasma sex hormones, and biogenic amine turnover in a forensic population of rapists. J. Sex. Marital Ther. 2003, 29, 215-225. [CrossRef]

24. Giotakos, O.; Markianos, M.; Vaidakis, N.; Christodoulou, G.N. Sex hormones and biogenic amine turnover of sex offenders in relation to their temperament and character dimensions. Psychiatry Res. 2004, 127, 185-193. [CrossRef]

25. Council of Europe. Annual Penal Statistics, SPACE I, Survey 2011. Strasbourg 3 May 2013, PC-CP \space $\backslash$ documents $\backslash P C-C P(2013) 5$. Available online: http://www3.unil.ch/wpmu/space/files/2014/04/ SPACE1_2011_English.pdf (accessed on 21 April 2018).

26. Amnesty International. Amnesty International Annual Report 2013-Greece, 23 May 2013. Available online: http://www.refworld.org/docid/519f519b4b.html (accessed on 21 April 2018).

27. Council of Europe's Committee for the Prevention of Torture and Inhuman or Degrading Treatment or Punishment, Report 2012. Available online: http://www.cpt.coe.int/documents/grc/2012-01-inf-eng.pdf (accessed on 1 February 2019). 
28. Council of Europe's Committee for the Prevention of Torture and Inhuman or Degrading Treatment or Punishment, Report 2013. Available online: http://www.cpt.coe.int/documents/grc/2014-10-16-eng.htm (accessed on 1 February 2019).

29. Struckman-Johnson, C.; Struckman-Johnson, D. A comparison of sexual coercion experiences reported by men and women in prison. J. Interpers. Violence 2006, 21, 1591-1615. [CrossRef]

30. Hensley, C.; Koscheski, M.; Tewksbury, R. Examining the characteristics of male sexual assault targets in a southern maximum-security prison. J. Interpers. Violence 2005, 20, 667-679. [CrossRef]

31. Tewksbury, R. Fear of sexual assault in prison inmates. Prison J. 1989, 69, 62-71. [CrossRef]

32. Rosenberg, M. Society and the Adolescent Self-Image; Princeton University Press: Princeton, NJ, USA, 1965.

33. Koumi, I.; Tsiantis, J. Smoking trends in adolescence: Report on a Greek school-based peer-led intervention aimed at prevention. Health Promot. Int. 2001, 16, 65-72. [CrossRef] [PubMed]

34. Papadakaki, M.; Tzamalouka, G.S.; Chatzifotiou, S.; Chliaoutakis, J. Seeking for risk factors of Intimate Partner Violence (IPV) in a Greek national sample: The role of self-esteem. J. Interpers. Violence 2009, 24, 732-750. [CrossRef] [PubMed]

35. Richters, J.; Butler, T.; Schneider, K.; Yap, L.; Kirkwood, K.; Grant, L.; Richards, A.; Smith, A.M.; Donovan, B. Consensual sex between men and sexual violence in Australian prisons. Arch. Sex. Behav. 2012, 41, 517-524. [CrossRef]

36. Wolff, N.; Shi, J. Patterns of victimization and feelings of safety inside prison: The experience of male and female inmates. Crime Delinq. 2011, 57, 29-55. [CrossRef]

37. Struckman-Johnson, C.; Struckman-Johnson, D. Sexual coercion rates in seven midwestern prison facilities for men. Prison J. 2000, 80, 379-390. [CrossRef]

38. Gear, S. Behind the Bars of Masculinity: Male Rape and Homophobia in and About South African Men's Prisons. Sexualities 2007, 10, 209-216. [CrossRef]

39. Robertson, J.E. A clean heart and an empty head: The Supreme Court and sexual terrorism in prison. North Carol Law Rev. 2003, 81, 434-482.

40. Felson, R.B.; Cundiff, P.; Painter-Davis, N. Age and sexual assault in correctional facilities: A blocked opportunity approach. Criminology 2012, 50, 887-911. [CrossRef]

41. Lara, A. Forced integration of gay, bisexual and transgendered inmates in California state prisons: From protected minority to exposed victims. South Calif. Interdiscip. Law J. 2010, 19, 589-594.

42. Innes, C.A. Patterns of misconduct in the federal prison system. Crim. Justice Rev. 1997, 22, 157-174. [CrossRef]

43. Koulouris, N.K.; Aloskofis, W. Prison Conditions in Greece; European Prison Observatory Press: Rome, Italy, 2013.

44. Berg, M.T.; DeLisi, M. The correctional melting pot: Race, ethnicity, citizenship, and prison violence. J. Crim. Justice 2006, 34, 631-642. [CrossRef]

45. Gover, A.R.; MacKenzie, D.L.; Armstrong, G. Importation and deprivation explanations of juveniles' adjustment to correctional facilities. Int. J. Offender Ther. Comp. Criminol. 2000, 44, 450-467. [CrossRef]

46. Broadus, K. The Criminal Justice System and Trans People. Temple Political \& Civil Rights Low Rev. 2009, 561, 569-575.

47. National Prison Rape Elimination Report; NPREC Press: Washington, DC, USA, 2011. Available online: https://www.ncjrs.gov/pdffiles1/226680.pdf (accessed on 3 February 2019).

48. Special Rapporteur on Torture to the Human Rights Council, UN. 2001. Available online: https://www.ohchr. org/Documents/Issues/Discrimination/A.HRC.19.41_English.pdf (accessed on 3 February 2019).

49. Gear, S.; Ngubeni, K. Daai Ding: Sex, Sexual Violence and Coercion in Men's Prisons; Centre for the Study of Violence and Reconciliation Press: Johannesburg, South Africa, 2002.

50. Gear, S. Fear, Violence and Sexual Violence in a Gauteng Juvenile Correctional Centre for Males; Briefing Report No 2; Centre for the Study of Violence and Reconciliation Press: Johannesburg, South Africa, 2007.

51. Wolff, N.; Shi, J.; Blitz, C.; Siegel, J. Understanding sexual victimization inside prisons: Factors that predict risk. Criminol. Public Policy 2007, 6, 201-231. [CrossRef]

52. Anderson, C.L. Males as Sexual Assault Victims. J. Homosex. 1982, 7, 2-3. [CrossRef]

53. Banbury, S. Coercive sexual behavior in British prisons as reported by adult ex-prisoners. Howard J. Crim. Justice 2004, 43, 2-113. [CrossRef] 
54. Alarid, L.F. Sexual perspectives of incarcerated bisexual and gay men: The county jail protective custody experience. Prison J. 2000, 80, 1-80. [CrossRef]

55. Beck, A.J.; Hughes, T. Sexual Violence Reported by Correctional Authorities, 2004; NCJ-210333; U.S. Department of Justice, Bureau of Justice Statistics Press: Washington, DC, USA, 2005.

56. Byrne, J.M.; Hummer, D. Myths and realities of prison violence: A review of the evidence. Vict. Offender 2007, 2, 77-90. [CrossRef]

57. Fowler, K.S.; Blackburn, G.A.; Marquart, W.J.; Mulling, L.J. Inmates cultural beliefs about sexual violence and their relationship to definitions of sexual assault. J. Offender Rehabil. 2010, 49, 180-190. [CrossRef]

58. Rumney, P.N. Policing male rape and sexual assault. J. Crim. Law 2008, 72, 67-86. [CrossRef]

59. Robertson, J. "Turning-Out" of boys in a man's prison: Why and how we need to amend the prison rape elimination act. Indiana Law Rev. 2010, 44, 819-852.

60. Kubiak, S.P.; Brenner, H.; Bybee, D.; Campbell, R.; Fedock, G. Reporting Sexual Victimization During Incarceration: Using Ecological Theory as a Framework to Inform and Guide Future Research. Trauma Violence Abus. 2018, 19, 94-106. [CrossRef] [PubMed]

61. Giavrimis, P. The Training of Prison Guards: The Case of Greece. IJCST 2012, 5, 871-885.

62. Benedict, A. Using Trauma-Informed Practices to Enhance Safety and Security in Women's Correctional Facilities; National Resource Center on Justice Involved Women Press: Cincinnati, OH, USA, 2010.

63. Cloitre, M.; Koenen, K.; Cohen, L.; Han, H. Skills training plus exposure therapy may reduce post traumatic stress in women who experienced childhood sexual abuse. J. Consult. Clin. Psychol. 2002, 70, 1067-1074. [CrossRef]

64. Miller, N.A.; Najavits, L.M. Creating trauma-informed correctional care: A balance of goals and environment. Eur. J. Psychotramatol. 2012, 3, 17246. [CrossRef]

65. Substance Abuse and Mental Health Services Administration. Treatment Improvement Protocol; Series 57; Trauma-Informed Care in Behavioral Health Services (TIP): Rockville, MD, USA, 2014.

66. Eggert, E. Violence and Silence: The Prison Rape Elimination Act and Beyond. Tapestries Interwoven Voices Local Glob. Identities 2018, 7, 6. Available online: http://digitalcommons.macalester.edu/tapestries/vol7/iss1/6 (accessed on 1 February 2019).

67. Bureau of Justice Statistics Status Report: Data Collections for the Prison Rape Elimination Act of 2003; Bureau of Justice Statistics Press: Washington, DC, USA, 2004.

68. Struckman-Johnson, C.; Struckman-Johnson, D. Stopping prison rape: The evolution of standards recommended by PREA's National Prison Rape Elimination Commission. Prison J. 2013, 93, 335-354. [CrossRef]

69. Hensley, C.; Castle, T.; Tewksbury, R. Inmate-to-inmate sexual coercion in a prison for women. J. Offender Rehabil. 2003, 37, 77-87. [CrossRef]

(C) 2019 by the authors. Licensee MDPI, Basel, Switzerland. This article is an open access article distributed under the terms and conditions of the Creative Commons Attribution (CC BY) license (http://creativecommons.org/licenses/by/4.0/). 